\title{
A trama de vínculos na história de um representante sindical ${ }^{\star}$
}

\author{
Augusto Dutra Galery ${ }^{\text {Orcid, } \star \star ~}$ \\ Universidade de São Paulo, São Paulo, SP, Brasil
}

Palavras-chave: vínculo; democracia; René Kaës; Eugène Enriquez.

Partimos da hipótese teórica de que a organização democrática de grupos institucionalizados, na qual um representante é eleito pelo voto dos demais integrantes do grupo, pode cumprir uma função psíquica de intermediário, na acepção de KAËS (2005). A função do intermediário, nesse caso, é mediar os espaços intersubjetivos, "na ordem da vida social e da cultura" (KAËS, 2005, p. 12). Sugere-se, portanto, que o representante democrático pode ocupar tal papel entre os membros do grupo e o poder. Pensamos tal hipótese a partir de Freud (1913/2012, p. 49) quando afirma, em Totem e Tabu: “Ainda Moisés tem de atuar como intermediário entre seu povo e Jeová, já que o povo não suportaria a visão de Deus, e quando ele retorna da presença de Deus seu rosto brilha, uma parte do 'maná' transferiu-se para ele, como sucede com o intermediário nos povos primitivos".

Por outro lado, a função da organização democrática da liderança é garantir a possibilidade de expulsão do líder, caso ele represente uma ruptura para o Ideal de Eu dos integrantes do grupo frente ao seu projeto comum, na concepção de Enriquez (2001). Tal hipótese aparece a partir das concepções de democracia de Barus-Michel (2001).

Para abordar o tema, utilizamos o método de entrevista de história de vida, tendo como sujeito de pesquisa um sindicalista que, por 20 anos seguidos, atuou em um sindicato ligado à justiça federal. A partir dos dados obtidos, foi possível levantar a hipótese de que o representante identifica seu Ideal do Eu com os ideais do grupo, podendo postergar a satisfação de seus desejos em troca de ser reconhecido pelo grupo. O representante, assim, recebe uma transferência de poder para exercer funções típicas do papel de intermediário, mas, através da organização democrática, o grupo mantém o poder de destituí-lo de seu papel e massacrá-lo (mesmo que simbolicamente).

Pensamos que a história do representante sindical foi uma ilustração rica que nos permitiu algumas considerações: 1) o representante eleito ocupou, por diversas vezes, o papel de intermediário entre as descontinuidades dos diversos grupos que se entrelaçavam na composição do sindicato; 2) ao se posicionar como representante, o entrevistado teve que abrir mão de seus ideais e de sua satisfação, que não deixaram de existir, mas ficaram adiadas; 3) a manutenção da aliança teve um alto custo psíquico, em forma de sofrimento, mas que parece ser compensado pela manutenção de outros vínculos; 4) a ruptura da aliança entre o entrevistado e a direção do sindicato relacionou-se com um investimento narcísico do entrevistado (como proteção ao Eu, mas também como potência); e 5) o entrevistado, investido em seu narcisismo, foi colocado pelos membros do grupo na posição de "pai da horda" e simbolicamente assassinado pelo grupo, na forma de exclusão e ostracismo, o que foi vivido, pelo próprio entrevistado, como um luto.

\section{Referências}

BARUS-MICHEL, Jacqueline. A democracia ou a sociedade sem pai. In: ARAÚJO, José Newton Garcia de.; SOUKI, Léa Guimarães; FARIA, Carlos Aurélio Pimenta (Org.). Figura Paterna e Ordem Social. Belo Horizonte: PUC Minas, 2001. p. 29-39.

ENRIQUEZ, Eugène. O Vínculo Grupal. In: MACHADO, Marília Novais da Mata et al. (Org.). Psicossociologia: análise social e intervenção. Belo Horizonte: Autêntica, 2001. p. 61-74.

FREUD, Sigmund. Totem e Tabu (1913). São Paulo: Companhia das Letras/Penguin, 2012.

KAËS, René. Os espaços psíquicos comuns e partilhados: transmissão e negatividade. São Paulo: Casa do Psicólogo, 2005.

\footnotetext{
^ Tese apresentada ao Instituto de Psicologia da Universidade de São Paulo como parte dos requisitos para obtenção do grau de Doutor em Psicologia Social. Fonte de financiamento: Coordenação de Aperfeiçoamento de Pessoal de Nível Superior (Capes).

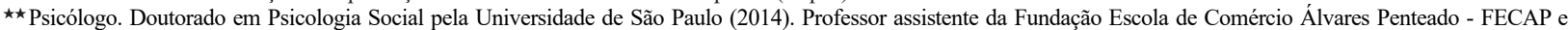
professor convidado do curso de mestrado profissional e do CEAG da Escola de Administração de Empresas de São Paulo/Fundação Getúlio Vargas. E-mail: galery@usp.br
} 